\title{
Use of Flying Dragon Trifoliate Orange As Dwarfing Rootstock for Citrus Under Tropical Climatic Conditions
}

\author{
François Mademba-Sy ${ }^{1}$ \\ South Province, P.O. Box BP L1, 98849 Nouméa cedex, New Caledonia \\ Zacharie Lemerre-Desprez ${ }^{2}$ and Stéphane Lebegin \\ Tropical Fruit Crops, P.O. Box 32, Pocquereux Fruits Research Station, New \\ Caledonian Agronomic Institute, BP 32, 98880 La Foa, New Caledonia
}

Additional index words. New Caledonia, Poncirus trifoliata, cultivars trials, productivity, quality, costs, economic return

\begin{abstract}
Citrus fruit trees grown under tropical climatic conditions have a high level of vigor and, consequently, late fruit-bearing and low productivity. The use of Flying Dragon trifoliate orange [Poncirus trifoliata var. monstrosa (T.Itô) Swing.] (FD) rootstock could overcome these negative effects by inducing small trees with early production. Trials including eight commercial cultivars began in Dec. 1992 on an irrigated plot on the main island of New Caledonia (South Pacific). Growth of the trees was observed over a 13-year period through twice-yearly measurements of tree height, canopy between and in the rows, and trunk diameter. Fruit production was recorded beginning 2 years after planting. According to the climatic and pedological conditions of the experimental site, trees grafted on FD could, depending on cultivar, be planted in densities from 519 to 1111 trees/ha. Over the 13 years, yields were 0.5 to 2.8 times greater than those of the same cultivar on the standard rootstock. 'Tahiti' lime cumulative planting and maintenance costs were only 1.5 times higher for a density five times as great, and the level of productivity per hectare (gross margin/ha) was 3.3 times that of traditional orchards. Grafting citrus cultivars on FD, which is seldom used in the Mediterranean zone as a result of its excessive dwarfing effect in relation with the climatic conditions, could prove, on the other hand, promising in tropical areas.
\end{abstract}

In the tropical climatic zone, the vigor observed in citrus fruit trees represents a handicap for orchard development and limits yield increase of cultivated surface area. As a result, in New Caledonia, growers often plant at very low densities (150 to 200 plants/ ha) leading to poor sanitary conditions linked to the sizes of the trees to manage; pruning and harvesting operations for such trees result in high crop costs and low incomes. Such constraints become particularly troublesome when site topography hinders mechanical harvesting techniques. Various procedures to tree size control based on the use of pathogenic agents (Broadbent et al., 1986; Golomb, 1988), and specific horticultural or cultural techniques (Golomb, 1988; Krezdorn, 1978; Piner, 1988), have been tested. Pathogenic

\footnotetext{
Received for publication 28 Apr. 2011. Accepted for publication 5 Oct. 2011.

This research work was financed by the New Caledonian Public Organizations (French Government, New Caledonian Government, North, South and Loyalty Island Provinces) within the framework of Inter-Public Organizations Development Contracts, ensuring the funding of the Pocquereux Fruit Research Station.

We thank the staff of the nursery and the farm of the research station for their long-term involvement.

${ }^{1}$ Project Leader for Research and Development.

${ }^{2}$ To whom reprint requests should be addressed; e-mail lemerre@iac.nc.
}

agents can induce numerous drawbacks and are not easily introduced to areas where they are absent or could present the risk of mutation toward more virulent forms. On the other hand, propagation and cultural techniques that are unreliable and/or expensive have not been yet exploited by nurserymen. The most researched method has been the use of rootstocks, which has also shown to be reliable and simple. In the deciduous fruit industries of the world, particularly apple, size-controlling rootstocks have been very effective in relation with the availability of suitable plant material (Webster, 1997, 2004). With citrus, only a few rootstocks have shown any potential for consistent size control and the best one has been Flying Dragon trifoliate orange (Bitters et al., 1979) in association with good yield and fruit quality (Roose, 1986).

The term "dwarfing" can only be applied to rootstocks that reduce tree volume by at least $75 \%$, thus limiting tree height to $2.5 \mathrm{~m}$ at adult age (Bitters et al., 1979). FD would be one such dwarfing rootstock. Originating from Japan, it was used to produce ornamental potted plants and introduced in the United States by Walter S. Swingle in 1915; it remained for long as a botanical curiosity. Thereafter, economic considerations led researchers to identify dwarfing rootstock, which would make it possible to increase planting densities and, consequently, yields. Like Poncirus trifoliata, of which it is a mutant (Castle, 1992), FD has tolerance traits toward citrus tristeza virus, resistance traits toward Phytophthora spp. and citrus nematodes as well as a good level of tolerance for cultivation in heavy soils. Its use requires the selection of scions, which are free of exocortis, a degenerative viroid disease to which Poncirus and their hybrids are very sensitive.

Taking into account this overall set of characteristics, the objective of this trial was to determine the potential of FD dwarfing rootstock under New Caledonian climatic conditions at the Pocquereux Fruit Research Station with citrus cultivars actually planted for local fresh market (orange, mandarin, grapefruit) and for export to Australia and New Zealand (Tahiti lime). New Caledonian global citrus production has reached $3000 \mathrm{t}$ in 2009 (DAVAR, 2010). Expected results would be assigned to extension services to improve the profitability of the New Caledonian citrus industry.

\section{Materials and Methods}

Plant material. Flying Dragon trifoliate orange seeds were supplied for the trial in 1990 by Willits and Newcomb (U.S.A.). The trial was made up of eight cultivars grafted on this rootstock. These cultivars were introduced into New Caledonia from the San Giuliano, Corsica Inra Agronomic Research Station (SRA) and were free from known transmissible citrus diseases. Testing concerned 'Lisbon' lemon [Citrus limon (L.) Burm. F.] SRA 16, 'Orlando' tangelo ( $C$. reticulata Blanco $\times C$. paradisi Macf.) SRA 46, 'Tahiti' lime (C. latifolia Tan.) SRA 58, 'Valencia' orange [C. sinensis (L.) Osb.] SRA 105, 'Saint John' satsuma mandarin ( $C$. unshiu Marc.) SRA 108, 'Ortanique' tangor [C. reticulata Blanco $\times$ C. sinensis (L.) Osb.] SRA 110, 'Washington' navel orange [C. sinensis (L.) Osb.] SRA 203, and 'Star Ruby’ grapefruit (C. paradisi Macf.) SRA 293. Control trees were made up using as rootstock, respectively, Citrus volkameriana for lemon and lime and Troyer citrange for the other cultivars. The evaluation was done under safe sanitary situation, i.e., no major citrus diseases are present in the experimental area such as citrus tristeza virus, citrus canker, and Huanglongbing.

Trial location, design, and management. New Caledonia, with 245,580 inhabitants (ISEE, 2009), is an archipelago of $19,100 \mathrm{~km}^{2}$ situated in the north of the Tropic of Capricorn between latitude $19^{\circ} \mathrm{S}$ and latitude $23^{\circ} \mathrm{S}$, longitude $158^{\circ} \mathrm{E}$ and longitude $172^{\circ} \mathrm{E}$ (Anonymous, 1989). Located on the Grande Terre, the main island, the Pocquereux Fruit Research Station, in La Foa village, is $15 \mathrm{~km}$ from the sea and at an altitude ranging from $18 \mathrm{~m}$ to $50 \mathrm{~m}$. The archipelago has a tropical climate with an annual average temperature of $22.5^{\circ}$, an average maximum of $28.5^{\circ} \mathrm{C}$, and an average minimum of $16.4^{\circ} \mathrm{C}$, which influence positively both the internal and external quality of fruits. The cool season (midMay to mid-September) makes the climatic 
conditions of the archipelago quite similar to the ones of subtropical citrus producing areas (South Florida, São Paulo State in Brazil) during the ripening period of the season and late oranges and mandarins cultivars. The annual rainfall average is $1294 \mathrm{~mm}$ with an average annual evapotranspiration of $1463 \mathrm{~mm}$ making it necessary to irrigate orchards.

The trees observed in the trial were planted on a hilly piedmont plot (lat. $21^{\circ} 43^{\prime} 53^{\prime \prime}$; long. $165^{\circ} 53^{\prime} 54^{\prime \prime}$, alt. $30 \mathrm{~m}$ ). The soil texture was heavy with the clay-loam combination equaling $66 \%$. Such soil is medium in organic matter content $(2 \%)$, very rich in magnesium, but very poor in potassium and calcium. It contains no sodium and $\mathrm{pH}$ is 5.6. These special characteristics (hypermagnesium soil, lacking in calcium, occasionally hydromorphic) can affect root growth, yield, and production size. Before improvement, the chosen flat plot had been covered by a dry forest composed of niaouli (Melaleuca quinquenervia). After bulldozer clearing, the soil was strongly enriched with $6 \mathrm{t} \cdot \mathrm{ha}^{-1}$ of lime (48\% calcium. The basic fertilization consisted of $2 \mathrm{t} \cdot \mathrm{ha}^{-1}$ deposit of $0 \mathrm{~N}-32 \mathrm{P}-16 \mathrm{~K}$ fertilizer. The ground was subsoiled with a ripper to a depth

Table 1. Correspondence and values (diameters, $\mathrm{mm}$ ) used for grading citrus in the trial conditions (New Caledonia) and European Union marketing standards.

\begin{tabular}{|c|c|c|c|c|c|c|}
\hline \multirow[b]{2}{*}{$\begin{array}{l}\text { Grade code } \\
\text { (NC) }\end{array}$} & \multicolumn{2}{|c|}{ Tangerines and hybrids } & \multicolumn{2}{|c|}{ Oranges } & \multicolumn{2}{|c|}{ Grapefruits } \\
\hline & $\begin{array}{l}\text { Diam } \\
(\mathrm{mm})\end{array}$ & $\begin{array}{c}\text { Grade code } \\
\text { (EU) }\end{array}$ & $\begin{array}{l}\text { Diam } \\
(\mathrm{mm})\end{array}$ & $\begin{array}{c}\text { Grade code } \\
\text { (EU) }\end{array}$ & $\begin{array}{l}\text { Diam } \\
(\mathrm{mm})\end{array}$ & $\begin{array}{l}\text { Grade cod } \\
\text { (EU) }\end{array}$ \\
\hline 1 & $45-56$ & 5 & $53-70$ & 13 to 9 & $70-85$ & 9,8 \\
\hline 2 & $57-62$ & $4,3,2$ & $71-76$ & 8,7 & $86-97$ & $7,6,5$ \\
\hline 3 & $63-67$ & 1 or $1-\mathrm{X}$ & $78-84$ & 6,5 & $98-106$ & 4 \\
\hline 4 & $68-71$ & 1 or $1-\mathrm{X}$ & $85-88$ & 4 & $107-116$ & 3,2 \\
\hline 5 & $>71$ & $1-\mathrm{XXX}, 1-\mathrm{XX}$ & $>88$ & $3,2,1,0$ & $>116$ & 1,0 \\
\hline
\end{tabular}

of $1 \mathrm{~m}$ (three teeth $1 \mathrm{~m}$ apart). Tilling was carried out to a depth of $45 \mathrm{~cm}$ with a fourblade plough, then the planting mounds were banked up by positioning the soil in the planting rows through repeated runs with the four-blade plough. The double rows of trees were situated in mounds that were $4 \mathrm{~m}$ long and $80 \mathrm{~cm}$ high along the central axis. The soil of the banked mounds was heavily mulched $(10 \mathrm{~cm})$ every year, in August, using 'Rhodes Grass' (Chloris gayana) produced on specially designed plots at the experimental station. The annual fertilization of $15 \mathrm{~N}-5 \mathrm{P}-19 \mathrm{~K}$ fertilizer for the trees was divided into three applications per year: $50 \%$ of the fertilization was deposited in July, i.e., 1 month before flowering, 25\% 2 months later, in September, and $25 \% 4$ months later, in November. Additional lime $(42 \%$ calcium) was applied annually $\left(2 \mathrm{t} \cdot \mathrm{ha}^{-1}\right)$ when trees reached 4 years old. The trial was planted in Dec. 1992. Planting density was 1000 trees/ha. Trees were planted in twin rows on the mound: $5 \mathrm{~m}$ separated each adjacent rows with $3 \mathrm{~m}$ between rows and $2.5 \mathrm{~m}$ between plants on the row. The eight cultivars on FD and controls were planted according to a four randomized complete blocks distribution. Controls were planted at the standard density of 208 trees/ha.

Data collection and statistical analysis. Every 6 months (January to July), beginning with planting, five measurements were taken: 1) canopy diameter along the planting line $\left(\mathrm{D}_{\text {line }}\right)$; 2) canopy diameter perpendicular to the planting line $\left.\left(\mathrm{D}_{\text {perp }}\right) ; 3\right)$ trunk diameter at $10 \mathrm{~cm}$ above the level of the graft; 4) trunk diameter at $10 \mathrm{~cm}$ below the level of the graft; and 5) tree height $(\mathrm{H})$. Canopy volume was calculated using the results of these measurements in the formula (Castle, 1983):

$$
\mathrm{V}=1 / 6 \pi \mathrm{HD}^{2}
$$

where

$$
\mathrm{D}=\left(\mathrm{D}_{\text {line }}+\mathrm{D}_{\text {perp }}\right) / 2
$$

Weighing of the production harvests began when the first fruit appeared, i.e., at the end of the second year after planting. Quality analyses were run on the harvested fruits of five cultivars, during season 2001, using standards laid out in international specification (Anonymous, 1988). These analyses were done on samples constituted of 10 fruits per tree picked every 3 weeks. In our climatic conditions, the maturity date is quite the same 1 year to another. 'Washington' is firstly sampled on 1 Feb., then every 3 weeks until maturity at the end of March. First sampling of 'St. John' satsuma is realized in late February until harvesting in mid-April. 'Orlando' is first sampled in late February and harvested at the end of May. Sampling of 'Ortanique' and 'Star Ruby' begins at the end of February and fruits are harvested in mid-June. Because 'Valencia' is a very late cultivar, first sampling

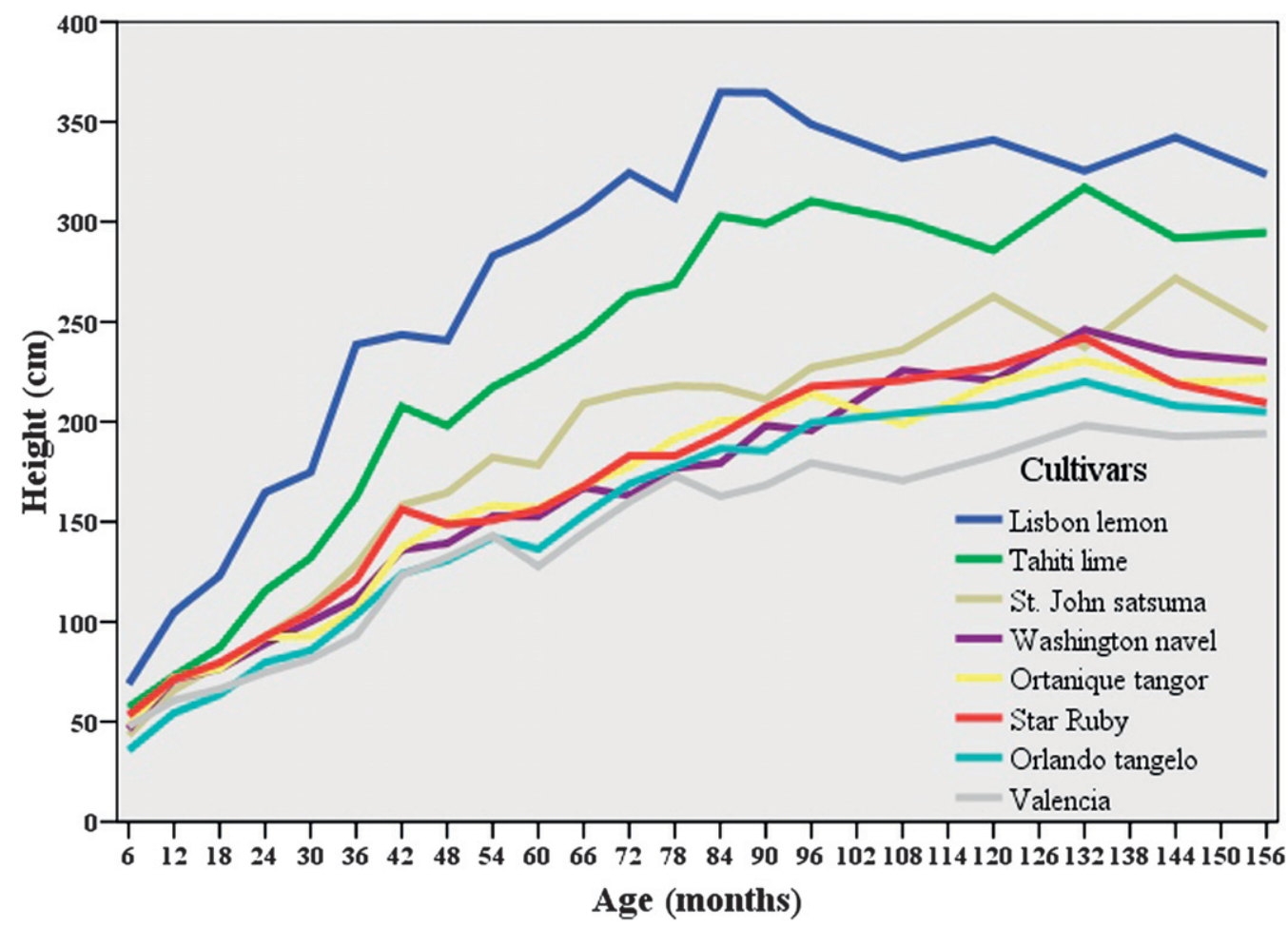

Fig. 1. Height growth of eight cultivars from 6 to 156 months grafted on Flying Dragon rootstock. 
begins in mid-May and harvesting at the end of July.

After the harvest, all the fruits from the experimental trees were graded to evaluate the commercial interest of the production. Batches of 30 fruits per cultivar allowed the characterization of these calibration classes in relation with the European Union official marketing standards (Anonymous, 2004) (Table 1). Statistical analyses were made by analysis of variance performed with SPSS $^{\circledR}$ 15.0 (SPSS Inc., Chicago, IL).

Financial analyses. The aim of this trial is to increase productivity, and thus profitability, for New Caledonia's citrus growers by using a new rootstock. The technical-economic evaluation, with 'Tahiti' lime, compares the planting and production costs of a highdensity "pedestrian orchard" (1000 trees/ha) grafted on dwarfing rootstock to that of a traditional orchard (208 trees/ha). Results are based on the analysis of the following costs: tree supply, land preparation, irrigation system, fertilizers, pest and disease management, pruning, harvesting, and amortization. Harvested 'Tahiti' lime is exported to New Zealand with an average annual sorting of $25 \%$.

\section{Results and Discussion}

Genetically uniform citrus rootstock can be propagated trough seed when the rootstock variety is apomictic. In the case of FD, however, zygotic original plants are frequent. Their percentage, varying from $0 \%$ to $75 \%$, runs at an average of 50\% (Cheng and Roose, 1995). Even if visual sorting makes it possible to distinguish nucellar subjects (bent thorns and spiral growth of shoots), certain zygotic plants also have phenotypic features like those of nucellar plants. Identification of atypical subjects can be made very reliably on the basis of isoenzymatic polymorphism (Ollitrault, 1990). Enzymatic analysis carried out at the Pocquereux Station laboratory in 1997 made it possible to identify a posteriori only $2.7 \%$ zygotic subjects out of the plants of the trial. Visual sorting in the nursery, is, therefore, relatively efficient and trees measured in this trial are true to type.

Tree height and canopy volume. Tree growth was slow over the first 5 years of observation (Fig. 1). At that stage, the dwarfing effect is obvious no matter what cultivar has been grafted on FD rootstock. In comparison with the control, significant height reduction was noted in all cultivars grafted on FD. Among the eight cultivars tested, the 'Tahiti' lime and the 'Lisbon' lemon revealed to be the most vigorous. The height rose above $2.5 \mathrm{~m}$ between Years 4 and 5.5 with the $3-\mathrm{m}$ growth plateau being reached at 7 years. At 13 years, less reduction in height was noted on 'Tahiti' lime (66\%), 'Lisbon' lemon (66\%), and 'Saint John' satsuma (40\%) (Table 2). For these combinations, FD could be considered as a semidwarfing rootstock regarding height. These results on 'Tahiti' lime are similar to the observations made in Brazil (Stuchi et al., 2003). The effect of cyclones was noted for 'Lisbon' lemon and 'Tahiti' lime on FD (main branches broken with, respectively, $31 \%$ and $6 \%$ of trees dead). The five other cultivars grafted on FD did not exceed a height of $2.5 \mathrm{~m}$, which was reached in 7 to 8 years and were unaffected by cyclones. The reduction in height was most significant for 'Valencia' (186\%) and least significant for 'Orlando' tangelo and 'Star Ruby' grapefruit (100\%). For these combinations, the reduction of height is more than $75 \%$ compared with the control so that FD should be considered as a dwarfing rootstock.

The canopy volume at 13 years clearly shows the dwarfing effect of FD and these results confirm the described tendencies concerning height (Table 2). The reduction in volume in comparison with the controls is greatest for 'Valencia' (17 times) and least for 'St. John' satsuma (2.7 times). Whereas FD is not considered as dwarfing for 'Tahiti' lime, 'Lisbon' lemon, and 'St. John' satsuma regarding height, it contributed to a canopy volume reduction of, respectively, six, four, and almost three times (Fig. 2). Using the interpretation of this variable would allow planting intervals to be adapted depending on the canopy volume shown by the eight tested cultivars. The double-row planting in this trial did not lend itself to mechanize cultural practices; especially weed control between the rows. Based on planting in single rows, the canopy volume measurements would enable the planting intervals and, therefore, the density, to be established and retained as shown in Table 3.

In all the cases, the scion-stock compatibility resulting from the scion/stock diameters ratio is lower for the cultivars grafted on FD

Table 2. Height and canopy volume for 13-year-old trees from citrus cultivars grafted on Flying Dragon (FD) under New Caledonian climatic conditions.

\begin{tabular}{|c|c|c|c|c|c|c|}
\hline \multirow[b]{2}{*}{ Cultivars } & \multicolumn{2}{|c|}{ Ht (m) } & \multirow{2}{*}{$\begin{array}{c}\text { Reduction } \\
(\%)\end{array}$} & \multicolumn{2}{|c|}{ Canopy volume $\left(\mathrm{m}^{3}\right)$} & \multirow{2}{*}{$\begin{array}{c}\text { Reduction } \\
(\%)\end{array}$} \\
\hline & Control $^{z}$ & FD & & Control & FD & \\
\hline Valencia & $5.0 \mathrm{a}$ & $1.75 \mathrm{~b}$ & 186 & $70.3 \mathrm{a}$ & $4.0 \mathrm{~b}$ & 1657 \\
\hline Orlando tangelo & $4.0 \mathrm{a}$ & $2.0 \mathrm{~b}$ & 100 & $50.4 \mathrm{a}$ & $4.8 \mathrm{~b}$ & 950 \\
\hline Star Ruby & $4.0 \mathrm{a}$ & $2.0 \mathrm{~b}$ & 100 & $45.4 \mathrm{a}$ & $6.0 \mathrm{~b}$ & 657 \\
\hline Ortanique tangor & $4.5 \mathrm{a}$ & $2.0 \mathrm{~b}$ & 125 & $54.8 \mathrm{a}$ & $7.4 \mathrm{~b}$ & 641 \\
\hline Washington navel & $4.25 \mathrm{a}$ & $2.0 \mathrm{~b}$ & 112 & $49.3 \mathrm{a}$ & $7.4 \mathrm{~b}$ & 566 \\
\hline Tahiti lime & $5.0 \mathrm{a}$ & $3.0 \mathrm{~b}$ & 66 & $112 \mathrm{a}$ & $18 \mathrm{~b}$ & 522 \\
\hline Lisbon lemon & $5.0 \mathrm{a}$ & $3.0 \mathrm{~b}$ & 66 & $99.8 \mathrm{a}$ & $25.1 \mathrm{~b}$ & 298 \\
\hline St. John satsuma & $3.5 \mathrm{a}$ & $2.5 \mathrm{~b}$ & 40 & $34.4 \mathrm{a}$ & $12.7 \mathrm{~b}$ & 171 \\
\hline
\end{tabular}

${ }^{\mathrm{z}}$ Volkamer lemon for Lisbon and Tahiti, Troyer citrange for the others.

The compared means between control and FD followed by the same letter for a cultivar are not significantly different by analysis of variance $(P \leq 0.05)$.

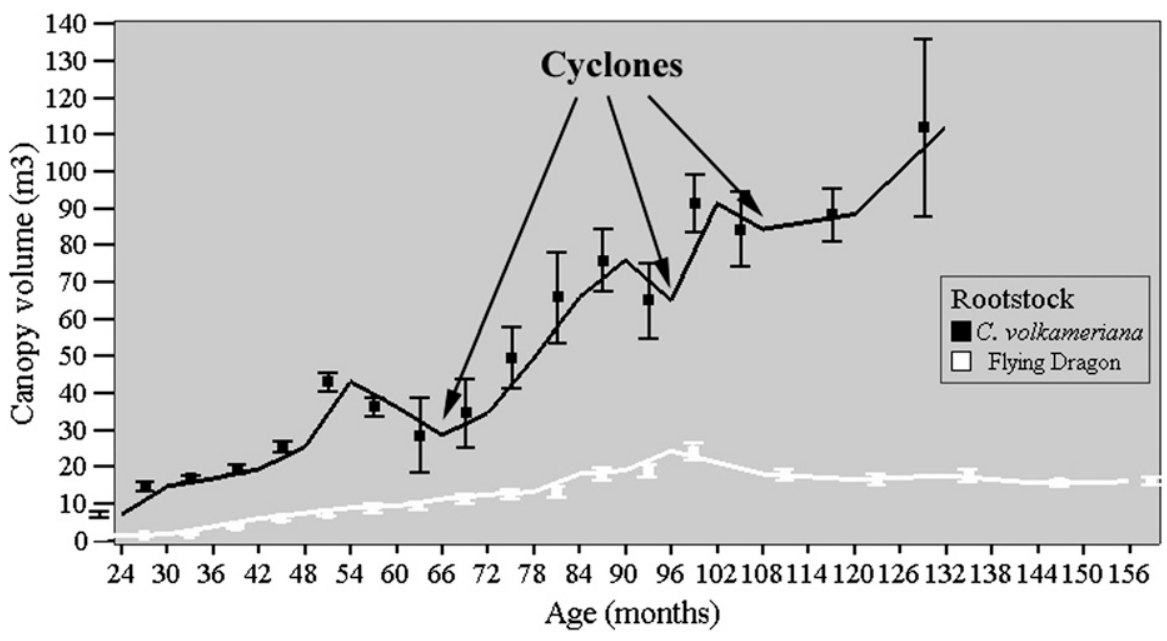

Fig. 2. Development of average canopy (24 to 156 months) of 'Tahiti' lime on two rootstocks.

Table 3. Proposed planting density according to canopy volume at 13 years and planting intervals for trees from citrus cultivars grafted on Flying Dragon in New Caledonia.

\begin{tabular}{lccc}
\hline Cultivars & Canopy volume $\left(\mathrm{m}^{3}\right)$ & Planting intervals $(\mathrm{m})$ & Proposed planting density (plants/ha) \\
\hline Valencia & 4.0 & $2 \times 4.5$ & 1111 \\
Orlando tangelo & 4.8 & $2 \times 4.5$ & 1111 \\
Star Ruby & 6.0 & $2 \times 4.5$ & 1111 \\
Ortanique tangor & 7.4 & $2.5 \times 4.5$ & 888 \\
Washington navel & 7.4 & $2.5 \times 4.5$ & 888 \\
St. John satsuma & 12.7 & $2.5 \times 5$ & 800 \\
Tahiti lime & 18.0 & $3 \times 5$ & 667 \\
Lisbon lemon & 25.1 & $3.5 \times 5.5$ & 519
\end{tabular}


Table 4. Comparison of ratios of scion/stock diameters for 13-year-old trees from citrus cultivars grafted on Flying Dragon (FD) and conventional rootstocks in New Caledonia.

\begin{tabular}{lcccc}
\hline & \multicolumn{3}{c}{ Ratio scion/stock diam } & \\
\cline { 2 - 4 } Cultivars & FD & Volkamer lemon & Troyer citrange & Difference (\%) \\
\hline $\begin{array}{l}\text { Tahiti lime } \\
\text { Washington }\end{array}$ & $0.60 \mathrm{a}$ & $0.92 \mathrm{~b}$ & $0.78 \mathrm{~b}$ & $53(\mathrm{~V}))^{\mathrm{y}} 37(\mathrm{~T})^{\mathrm{y}}$ \\
$\quad$ navel & $0.57 \mathrm{a}$ & $0.89 \mathrm{~b}$ & & 44 \\
Ortanique tangor & $0.52 \mathrm{a}$ & & $0.75 \mathrm{~b}$ & 33 \\
Lisbon lemon & $0.66 \mathrm{a}$ & $0.88 \mathrm{~b}$ & $0.71 \mathrm{~b}$ & 31 \\
Valencia & $0.54 \mathrm{a}$ & & $0.80 \mathrm{~b}$ & 19 \\
St. John satsuma & $0.67 \mathrm{a}$ & & $0.85 \mathrm{~b}$ & 18 \\
Orlando tangelo & $0.72 \mathrm{a}$ & & $0.86 \mathrm{~b}$ & 18 \\
Star Ruby & $0.73 \mathrm{a}$ & &
\end{tabular}

zTen years old.

${ }^{\mathrm{y}} \mathrm{V}=$ Volkamer lemon; $\mathrm{T}=$ Troyer citrange.

Means followed by the same letter for a cultivar are not significantly different by analysis of variance $(P \leq$ $0.05)$.

Table 5. Cumulative and calculated harvest for 5-year-old trees from citrus cultivars grafted on Flying Dragon (FD) planted at high density (1000 trees/ha) and ratios of comparison with the production of a conventional orchard (208 trees/ha) in New Caledonia.

\begin{tabular}{|c|c|c|c|c|c|c|}
\hline \multirow{3}{*}{$\begin{array}{l}\text { Cultivars } \\
\text { Results at } \\
5 \text { years }\end{array}$} & \multirow{2}{*}{\multicolumn{2}{|c|}{$\begin{array}{c}\text { Cumulative harvest } \\
(\mathrm{kg} / \text { tree })\end{array}$}} & \multirow{3}{*}{ 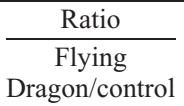 } & \multirow{2}{*}{\multicolumn{2}{|c|}{$\begin{array}{l}\text { Calculated cumulative } \\
\text { harvest }\left(\mathrm{t} \cdot \mathrm{ha}^{-1}\right)\end{array}$}} & \multirow{3}{*}{ 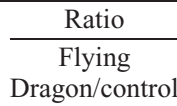 } \\
\hline & & & & & & \\
\hline & Control $^{z}$ & $\overline{F D}$ & & $\mathrm{Control}^{\mathrm{z}}$ & FD & \\
\hline St. John satsuma & $34 \mathrm{a}$ & $57 \mathrm{~b}$ & 1.7 & 7 & 57 & 8.1 \\
\hline Tahiti lime & $78 \mathrm{a}$ & $83 \mathrm{a}$ & 1.1 & 16 & 83 & 5.2 \\
\hline Lisbon lemon & $72 \mathrm{a}$ & $75 \mathrm{a}$ & 1.0 & 15 & 75 & 5.0 \\
\hline Star Ruby & 96 a & $71 \mathrm{a}$ & 0.7 & 20 & 71 & 3.5 \\
\hline Ortanique tangor & $62 \mathrm{a}$ & $39 \mathrm{~b}$ & 0.6 & 13 & 39 & 3.0 \\
\hline Orlando tangelo & $82 \mathrm{a}$ & $40 \mathrm{~b}$ & 0.5 & 17 & 40 & 2.3 \\
\hline Washington navel & $72 \mathrm{a}$ & $26 \mathrm{~b}$ & 0.4 & 15 & 26 & 1.7 \\
\hline Valencia & $115 \mathrm{a}$ & $25 \mathrm{~b}$ & 0.2 & 24 & 25 & 1.0 \\
\hline
\end{tabular}

${ }^{z}$ Volkamer lemon for Lisbon and Tahiti, Troyer citrange for the others.

Means followed by the same letter for a cultivar are not significantly different by analysis of variance $(P \leq$ $0.05)$.

Table 6. Cumulative and calculated harvest for 13-year-old trees from citrus cultivars grafted on Flying Dragon (FD) planted at high density (1000 trees/ha) and ratios of comparison with the production of a conventional orchard (208 trees/ha) in New Caledonia.

\begin{tabular}{|c|c|c|c|c|c|c|}
\hline \multirow{3}{*}{$\begin{array}{l}\text { Cultivar } \\
\text { Results at } \\
13 \text { years }\end{array}$} & \multirow{2}{*}{\multicolumn{2}{|c|}{$\begin{array}{c}\text { Cumulative harvest } \\
(\mathrm{kg} / \text { tree })\end{array}$}} & \multirow{3}{*}{$\begin{array}{c}\text { Ratio } \\
\text { Flying } \\
\text { Dragon/control }\end{array}$} & \multirow{2}{*}{\multicolumn{2}{|c|}{$\begin{array}{l}\text { Calculated cumulative } \\
\text { harvest }\left(\mathrm{t} \cdot \mathrm{ha}^{-1}\right)\end{array}$}} & \multirow{3}{*}{$\frac{\text { Ratio }}{\text { Flying }}$} \\
\hline & & & & & & \\
\hline & Control $^{z}$ & FD & & Control $^{z}$ & $\overline{F D}$ & \\
\hline Tahiti lime & $962 \mathrm{a}$ & $569 \mathrm{~b}$ & 0.8 & 200 & 569 & 2.8 \\
\hline St. John satsuma & $457 \mathrm{a}$ & $227 \mathrm{~b}$ & 0.5 & 95 & 227 & 2.4 \\
\hline Lisbon lemon & $736 \mathrm{a}$ & $330 \mathrm{~b}$ & 0.4 & 153 & 330 & 2.2 \\
\hline Star Ruby & $947 \mathrm{a}$ & $376 \mathrm{~b}$ & 0.4 & 197 & 376 & 1.9 \\
\hline Washington navel & $764 \mathrm{a}$ & $194 \mathrm{~b}$ & 0.2 & 159 & 194 & 1.2 \\
\hline Ortanique tangor & $1178 \mathrm{a}$ & $256 \mathrm{~b}$ & 0.2 & 245 & 256 & 1.0 \\
\hline Orlando tangelo & $995 \mathrm{a}$ & $205 \mathrm{~b}$ & 0.2 & 207 & 205 & 1.0 \\
\hline Valencia & $1394 \mathrm{a}$ & $154 \mathrm{~b}$ & 0.1 & 290 & 154 & 0.5 \\
\hline
\end{tabular}

${ }^{\mathrm{z}}$ Volkamer lemon for Lisbon and Tahiti, Troyer citrange for the others.

Means followed by the same letter for a cultivar are not significantly different by analysis of variance $(P \leq$ $0.05)$. than for the control (Table 4). The difference of compatibilities between FD and controls is less important for 'Star Ruby' and 'Orlando' $(18 \%)$ than for 'Tahiti' lime (53\%). Results show that this ratio cannot be linked to the dwarfing effect of FD (particularly for 'Lisbon' lemon and 'Tahiti' lime).

Yield and productivity. The yield comparison analysis gives an illustration of the temporal changes in productivity resulting from use of the different rootstocks. At 5 years (Table 5), 'St. John' satsuma cumulative per tree yield ranks higher than that of the control, whereas 'Lisbon' lemon, 'Tahiti' lime, and 'Star Ruby' are not significantly different. Harvests from the other cultivars are lower than the control. Taking all the cultivars together, the dwarfing rootstock production per hectare is at least equal for 'Valencia' to 8.1 times higher for 'St. John' satsuma than the control. Five years after planting, the yield from 'Tahiti' lime grafted on FD is double than the observations made in Brazil (Stuchi et al., 2003). At 13 years, lowest and highest FD cumulative yields per hectare (respectively, 'Valencia' and 'Tahiti' lime) are larger than the control (respectively, 'St. John' satsuma and 'Valencia') (Table 6). Taking all cultivars together, the dwarfing rootstock production per hectare is 0.5 to 2.8 times higher than the control. Overall, when using the FD dwarfing rootstock, the production per planted hectare is earlier and superior to the control, especially with 'Tahiti' lime scion (Fig. 3).

The productivity calculated initially from the average annual weighted production data and canopy volume ratio $\left(\mathrm{g} \cdot \mathrm{m}^{-3}\right)$ (Whitney et al., 1995) gives an illustration of the profitability resulting from use of the different rootstocks (Table 7). Three cultivar groups emerged: 'Tahiti' lime, 'Ortanique' tangor, 'Star Ruby' and 'Valencia', with an average production of $80 \%$ to $120 \%$ higher than the control; 'Orlando' tangelo, 'Lisbon' lemon, and 'Washington', whose average production is $50 \%$ to $70 \%$ higher than the control; and 'St. John' satsuma with an average production $30 \%$ higher than the control. In every case the productivity is significantly higher than the one of the control and is in accordance with

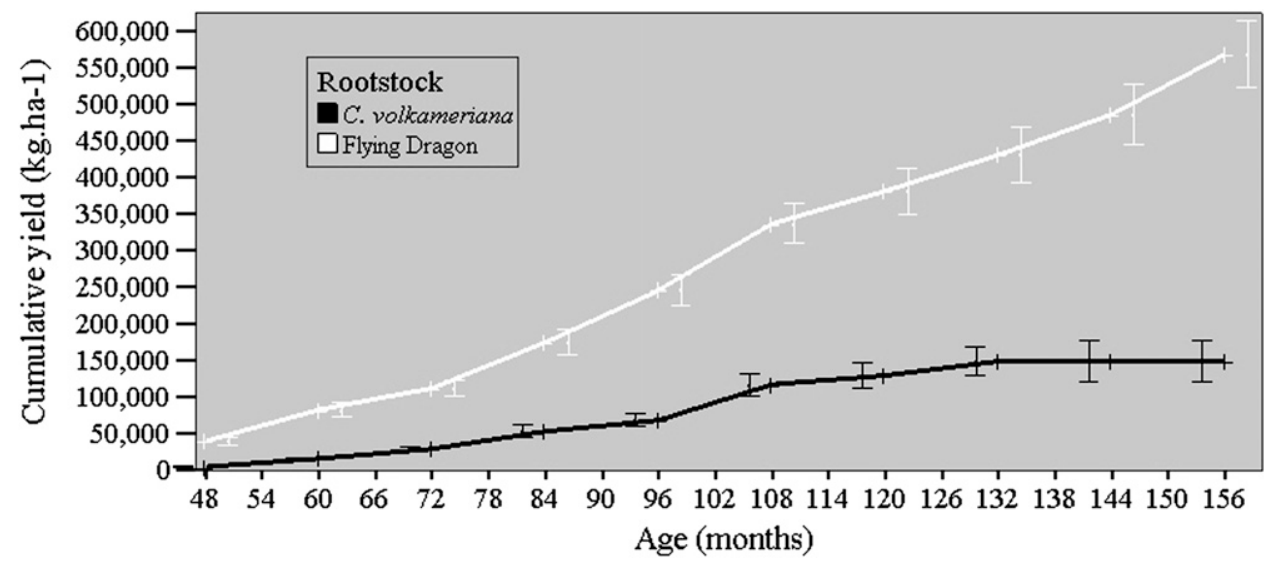

Fig. 3. Cumulative yields (48 to 156 months) of 'Tahiti' Lime on two rootstocks. 
the results mentioned for 'Washington' and 'Valencia' on FD in Italy (Reforgiato Recupero et al., 1992).

Fruit quality. The general average weight is reflected in the grades (Table 8). Except for 'Star Ruby', the use of FD increases the proportion of smaller fruits. Thus, two-thirds of the 'Valencia' production is Grade 1 on FD, whereas it is one-fourth on the control. Similar comments apply to 'Ortanique', 'Orlando', and 'Washington'. As a result of the use of $\mathrm{FD}$, the production level per hectare compensates for the grade reduction. These observations have already been reported in an experiment with the Limoneira 8A cultivar grafted on two rootstocks, one of which was FD, in Chile (Joublan and Cordero, 2002), and it is well known that trifoliate orange has the characteristic of inducing smaller fruits (Castle et al., 1993). Retail fresh fruit price is expensive in New Caledonia. Thus, having reasonably more fruits per kilogram is more attractive for consumers.

Juice content is increased for 'Washington' on FD and similar for 'Star Ruby' (Table 9). The other cultivars have lower values than

Table 7. Weighted average productivity for 13-year-old trees from citrus commercial cultivars grafted on Flying Dragon (FD) and ratio of comparison with the productivity of a conventional orchard in New Caledonia.

\begin{tabular}{|c|c|c|c|c|}
\hline \multirow[b]{2}{*}{ Cultivar } & \multicolumn{3}{|c|}{$\begin{array}{c}\text { Weighted avg productivity } \\
{\left[\text { harvest }(\mathrm{g}) / \text { canopy volume }\left(\mathrm{m}^{3}\right)\right]}\end{array}$} & \multirow{2}{*}{$\frac{\text { Ratio }}{\text { Flying Dragon/control }}$} \\
\hline & FD & Volkamer lemon & Troyer citrange & \\
\hline Tahiti lime & $3445 \mathrm{a}$ & $1565 \mathrm{~b}$ & & 2.2 \\
\hline Valencia & $4935 \mathrm{a}$ & & $2577 \mathrm{~b}$ & 1.9 \\
\hline Ortanique tangor & $4630 \mathrm{a}$ & & $2618 \mathrm{~b}$ & 1.8 \\
\hline Star Ruby & $7024 \mathrm{a}$ & & $3812 \mathrm{~b}$ & 1.8 \\
\hline Orlando tangelo & $5388 \mathrm{a}$ & & $3180 \mathrm{~b}$ & 1.7 \\
\hline Lisbon lemon & $1370 \mathrm{a}$ & $842 \mathrm{~b}$ & & 1.6 \\
\hline Washington navel & $3393 \mathrm{a}$ & $2282 \mathrm{~b}$ & $2158 \mathrm{~b}$ & $1.5(\mathrm{~V}),{ }^{\mathrm{z}} 1.6(\mathrm{~T})^{\mathrm{z}}$ \\
\hline St. John satsuma & $3084 \mathrm{a}$ & & 2418 b & 1.3 \\
\hline
\end{tabular}

${ }^{\mathrm{z}} \mathrm{V}=$ Volkamer lemon; $\mathrm{T}=$ Troyer citrange.

Means followed by the same letter for a cultivar are not significantly different by analysis of variance $(P \leq$ $0.05)$.

Table 8. Proportion of fruit (\%) according to commercial grades, of five citrus cultivars grafted on Flying Dragon (FD) and Troyer citrange (control) in New Caledonia.

\begin{tabular}{|c|c|c|c|c|c|c|c|c|c|c|}
\hline \multirow[b]{3}{*}{ Grade } & \multicolumn{4}{|c|}{ Tangerines and hybrids } & \multicolumn{4}{|c|}{ Oranges } & \multirow{2}{*}{\multicolumn{2}{|c|}{$\begin{array}{l}\text { Grapefruit } \\
\text { Star Ruby } \\
\end{array}$}} \\
\hline & \multicolumn{2}{|c|}{ Ortanique } & \multicolumn{2}{|c|}{ Orlando } & \multicolumn{2}{|c|}{ Valencia } & \multicolumn{2}{|c|}{ Washington navel } & & \\
\hline & $\overline{F D}$ & Control & FD & Control & $\begin{array}{l}\text { FD } \\
\end{array}$ & Control & FD & Control & FD & Control \\
\hline 1 & $6 \mathrm{a}$ & $<0 \mathrm{~b}$ & $11 \mathrm{a}$ & $7 \mathrm{a}$ & $67 \mathrm{a}$ & $24 \mathrm{~b}$ & $26 \mathrm{a}$ & $8 \mathrm{~b}$ & $38 \mathrm{a}$ & $30 \mathrm{a}$ \\
\hline 2 & $15 \mathrm{a}$ & $1 \mathrm{~b}$ & $26 \mathrm{a}$ & $28 \mathrm{a}$ & $22 \mathrm{a}$ & $37 a$ & $39 a$ & $21 \mathrm{~b}$ & $7 \mathrm{a}$ & $32 \mathrm{~b}$ \\
\hline 3 & $11 \mathrm{a}$ & $6 a$ & $14 \mathrm{a}$ & $7 \mathrm{~b}$ & $9 a$ & $35 \mathrm{~b}$ & $26 \mathrm{a}$ & $38 \mathrm{~b}$ & $19 \mathrm{a}$ & $20 \mathrm{a}$ \\
\hline 4 & $47 \mathrm{a}$ & $37 a$ & $14 \mathrm{a}$ & $7 \mathrm{~b}$ & $<1 \mathrm{a}$ & $3 \mathrm{~b}$ & $7 a$ & $21 \mathrm{~b}$ & $24 \mathrm{a}$ & $17 \mathrm{a}$ \\
\hline 5 & $21 \mathrm{a}$ & $56 \mathrm{~b}$ & $14 \mathrm{a}$ & $24 \mathrm{~b}$ & $<1 \mathrm{a}$ & $<1 \mathrm{a}$ & $2 \mathrm{a}$ & $12 \mathrm{~b}$ & $12 \mathrm{a}$ & $<1$ b \\
\hline
\end{tabular}

Means followed by the same letter for a cultivar are not significantly different by analysis of variance $(P \leq$ $0.05)$. the control. Whereas these last results have , the juin in Chile (Joublan and Cordero, and control) is far higher than the European Union marketing standards (Anonymous, 2004), certainly as a result of New Caledonian rootstock enhances the expression of the otal sugar content in comparison with the the cultivars grafted on FD, in comparison with the control, are significantly lower for 'Valencia' and 'Ortanique', Total acids for 'Orlando' and 'Star Ruby' are unaffected by the rootstock. The total soluble solids/total acidity (TSS/TA) ratio is significantly higher not affect this ratio in the case of 'Orlando' and 'Star Ruby'. In every case, TSS/TA is higher than 7. This ratio is likely to increase by the combination of using FD rootstock, vesting period, depending on which cultivars are cropped. The color of fruits (orange, tangor, and tangelo) is generally pronounced. This can be explained by the daily tempera- ture range as well as the low (less than 10 to $15{ }^{\circ} \mathrm{C}$ ) temperatures, which typify the New Caledonian tropical climate during the harvesting period (Mademba-Sy et al., 1994). Also, regardless of the rootstock, both the epicarp and the pulp of 'Orlando', 'Ortanique', and 'Valencia' (seasonal and late cultivars) develop a pronounced yellow-orange color. This appearance is a lot less pronounced in 'Washington' (an early cultivar) with a green to pale green epicarp, whereas the pulp tends toward yellow. In the case of 'Star Ruby', the epicarp is more prone to be yellow and pale pink, whereas the pulp tends to have an intense red color. To sum up, the use of FD enhances quality criteria of 'Washington' (juice content, TSS, TA, TSS/TA). The present results do not allow conclusions for other cultivars and require further observations on future harvests.

Economic analysis. The dwarfing effect of FD rootstock reduces tree growth rate, which makes technical interventions easier.

The costs for installing such a pedestrian orchard, in particular fertilization and soil preparation, are identical, regardless of the density (Table 10). Direct costs involved, proportional with the number of trees, are constructing the mounds and the purchase and the planting of the trees. Irrigation system modifications (one microjet for two trees) increased the latter by 1.1. In both cases, scion purchase and the irrigation system make up more than $70 \%$ of the outlay, whereas the most expensive cost in the pedestrian orchard is the trees in comparison with the conventional orchard. The cost of a dwarf grafted plant is more expensive than the standard one in relation with a higher length of propagation. Based on the analysis of the various cost items, the installation of a pedestrian orchard is 2.6 times more expensive than a conventional orchard, whereas the density is five times higher and so is not proportional.

Work undertaken in a pedestrian orchard is easier because of the reduced tree size and has a direct impact on operating costs such as pruning and harvesting. Thus, the operational cost of this type of orchard does not increase proportionately to the tree density; the weed control area of the rows is similar; the cumulative cost of pruning over 13 years, $\$ 9415$ for the pedestrian orchard and $\$ 7574$ for the conventional orchard, is multiplied by a factor of 1.2, taking into account the small tree size and diameter of branches. The cost of pests and disease control is

Table 9. Comparison of average fruit weight, juice content, total soluble solids (TSS), total acids (TA), and ratio (TSS/TA) of five citrus commercial cultivars grafted on Flying Dragon (FD) and Troyer citrange (control) in New Caledonia.

\begin{tabular}{|c|c|c|c|c|c|c|c|c|c|c|c|}
\hline \multirow[b]{2}{*}{ Cultivar } & \multirow[b]{2}{*}{ Harvest date } & \multicolumn{2}{|c|}{ Fruit wt (g) } & \multicolumn{2}{|c|}{ Juice content $(\%)$} & \multicolumn{2}{|c|}{ TSS ( ${ }^{\circ}$ Brix $)$} & \multicolumn{2}{|c|}{ TA $(\%)$} & \multicolumn{2}{|c|}{ Ratio TSS/TA } \\
\hline & & FD & Control & FD & Control & FD & Control & FD & Control & FD & Control \\
\hline Orlando tangelo & 7 May & $134 \mathrm{a}$ & $163 \mathrm{~b}$ & $53.1 \mathrm{a}$ & $55.8 \mathrm{~b}$ & $11.0 \mathrm{a}$ & $9.4 \mathrm{~b}$ & $1.1 \mathrm{a}$ & $1.0 \mathrm{a}$ & $10.3 \mathrm{a}$ & $9.8 \mathrm{a}$ \\
\hline Valencia & 25 July & $153 \mathrm{a}$ & $199 \mathrm{~b}$ & $49.7 \mathrm{a}$ & $58.3 \mathrm{~b}$ & $13.0 \mathrm{a}$ & $11.3 \mathrm{~b}$ & $1.7 \mathrm{a}$ & $1.2 \mathrm{~b}$ & $7.8 \mathrm{a}$ & $9.6 \mathrm{~b}$ \\
\hline Ortanique tangor & 26 June & $189 \mathrm{a}$ & $251 \mathrm{~b}$ & $54.8 \mathrm{a}$ & $57.4 \mathrm{~b}$ & $11.6 \mathrm{a}$ & $10.8 \mathrm{~b}$ & $1.7 \mathrm{a}$ & $1.1 \mathrm{~b}$ & $7.1 \mathrm{a}$ & $9.6 \mathrm{~b}$ \\
\hline Washington & 26 Mar. & $234 \mathrm{a}$ & $281 \mathrm{~b}$ & $47.8 \mathrm{a}$ & $43.3 \mathrm{~b}$ & $10.6 \mathrm{a}$ & $8.9 \mathrm{~b}$ & $0.9 \mathrm{a}$ & $1.1 \mathrm{~b}$ & $11.4 \mathrm{a}$ & $8.0 \mathrm{~b}$ \\
\hline Star Ruby & 6 June & $384 \mathrm{a}$ & $356 \mathrm{a}$ & $45.2 \mathrm{a}$ & $44.5 \mathrm{a}$ & $12.3 \mathrm{a}$ & $12.6 \mathrm{~b}$ & $1.7 \mathrm{a}$ & $1.8 \mathrm{a}$ & $7.5 \mathrm{a}$ & $7.2 \mathrm{a}$ \\
\hline
\end{tabular}

Means followed by the same letter for each criterion of a cultivar are not significantly different by analysis of variance $(P \leq 0.05)$. 
similar in both cases, because the volume of spray required to protect large citrus trees with normal density is offset by foliage work carried out in high-density orchards. Harvesting costs are multiplied by a factor of 1.9, whereas 'Tahiti' lime production is earlier and 2.8 times larger. This task is easier because the trees are more productive (ratio of quantity of limes produced by canopy unit). For harvest, cherry pickers or other specialized tools are not necessary. Fertilization costs based on expected harvest are, however, 2.5 times higher but are not proportionate to the density. The largest outlay concerns the inputs, which in both cases are over $40 \%$. The cost for operating and harvesting labor is $30 \%$ in both cases. Globally, the analysis of the different costs shows that operating a pedestrian orchard, aggregated over a 13-year period, is 1.4 times more expensive than a conventional orchard.
Based on 13 years of data concerning planting and maintaining, orchard installation costs redeemed over 10 years, and a 'Tahiti' lime average weighted price of $\$ 2.8 / \mathrm{kg}$, it appears that total expenditure is 1.5 times more expensive for the pedestrian orchard (\$173/tree) than for the traditional orchard (\$547/tree), whereas density is five times greater. The producing cost of $1 \mathrm{~kg}$ of 'Tahiti' lime on FD is 1.9 times lower. The expected turnover is 2.8 times higher and the cumulative gross margin 3.3 times higher. The cumulative gross margin graph (Fig. 4) shows the pedestrian orchard exceeding the breakeven point of $\$ 50,000$ in 4 years, whereas it is reached at 7 years for the conventional orchard. This assessment only incorporates the trial's direct costs. It does not take into consideration the infrastructural and indirect costs associated with a tropical fruit farming structure.

Table 10. Comparison of installation costs, maintenance costs, and gross margin per hectare (in US \$) for a 'Tahiti' lime pedestrian orchard at a high planting density (1000 trees/ha) and a conventional orchard at a low density (208 trees/ha) in New Caledonia.

\begin{tabular}{|c|c|c|c|c|c|}
\hline \multirow[b]{2}{*}{ Considered expenditure } & \multicolumn{2}{|c|}{ Pedestrian orchard cost } & \multicolumn{2}{|c|}{ Conventional orchard cost } & \multirow[b]{2}{*}{$\left.\left(\mathrm{C}_{\mathrm{po}}\right) / \mathrm{C}_{\mathrm{co}}\right)$} \\
\hline & US \$ $\left(\mathrm{C}_{\mathrm{po}}\right)$ & Percent & US $\$\left(\mathrm{C}_{\mathrm{co}}\right)$ & Percent & \\
\hline Soil preparation & 343 & 1 & 343 & 3 & 1.0 \\
\hline Basic fertilization & 2,264 & 7 & 2,264 & 17 & 1.0 \\
\hline Mounds construction & 458 & 1 & 267 & 2 & 1.7 \\
\hline Grafted plants & 19,703 & 58 & 3,213 & 25 & 6.1 \\
\hline Planting labor & 3916 & 12 & 783 & 6 & 5.0 \\
\hline Irrigation & 7,000 & 21 & 6,116 & 47 & 1.1 \\
\hline Global installation costs & 33,685 & 100 & 12,986 & 100 & 2.6 \\
\hline Labor & 27,126 & 20 & 22,018 & 22 & 1.2 \\
\hline Inputs & 63,315 & 46 & 42,040 & 42 & 1.5 \\
\hline Equipment operators & 34,194 & 25 & 29,189 & 29 & 1.2 \\
\hline Harvest & 14,423 & 10 & 7,605 & 8 & 1.9 \\
\hline Global maintenance costs & 139,058 & 100 & 100,851 & 100 & 1.4 \\
\hline Global Costs & 172,743 & & 113,837 & & 1.5 \\
\hline Turnover & $1,201,180$ & & 422,207 & & 2.8 \\
\hline Gross margin per hectare after 13 years & $1,028,437$ & & 308,370 & & 3.3 \\
\hline Direct cost per kilogram for 13 years & 0.30 & & 0.57 & & 0.53 \\
\hline
\end{tabular}

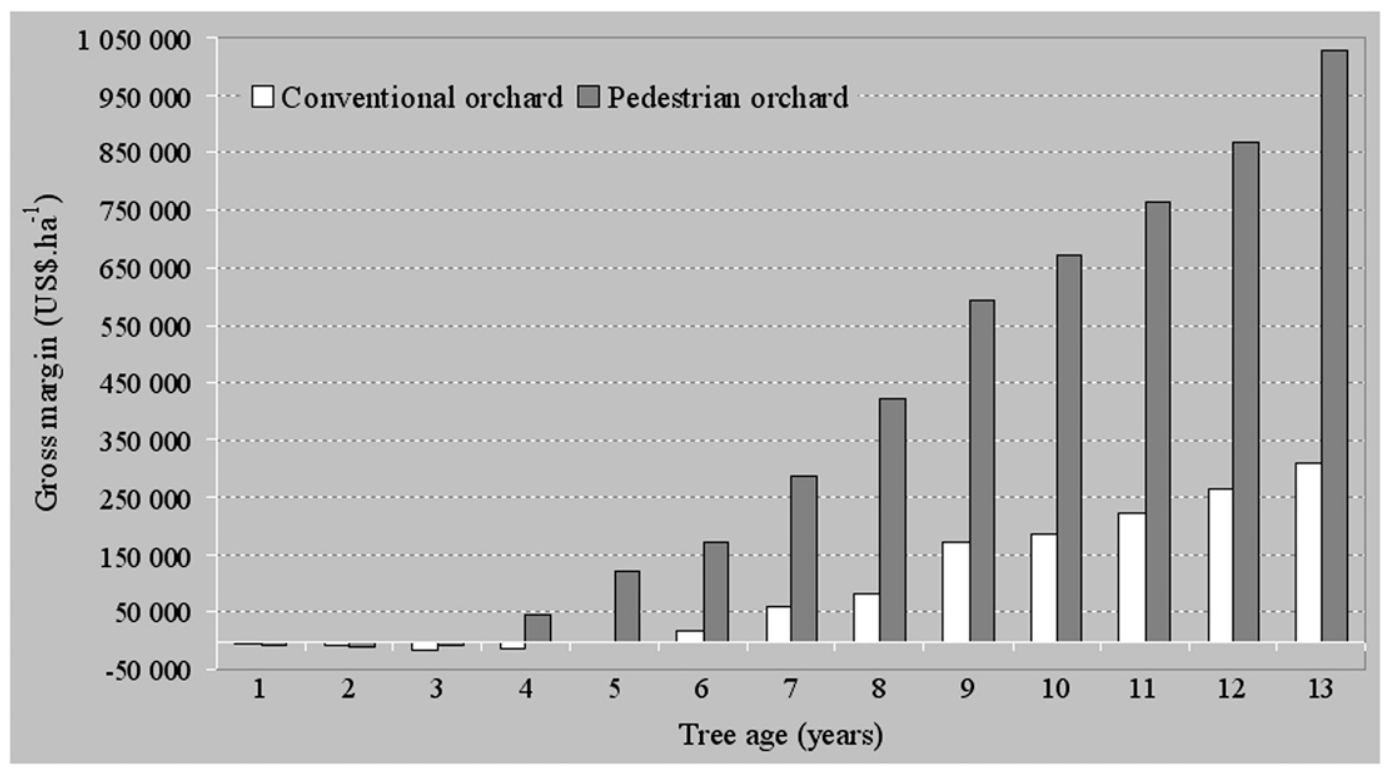

Fig. 4. Comparison of the gross margins aggregated over 13 years for a pedestrian orchard made up of 'Tahiti' lime trees grafted on dwarfing Flying Dragon rootstock and an orchard using conventional rootstock (New Caledonia). 


\section{Literature Cited}

Anonymous. 1988. Descriptors for citrus. IBPGR, FAO, Rome, Italy.

Anonymous. 1989. Atlas de Nouvelle-Calédonie, ORSTOM. Editions du Cagou. HachetteCalédonie, Nouméa.

Anonymous. 2004. Norme CEE-ONU FFV-14 concernant la commercialisation et le contrôle de la qualité commerciale des agrumes. Nations Unies, New York et Genève.

Bitters, W.P., D.A. Cole, and C.D. McCarthy. 1979. Facts about dwarf citrus trees. Citrograph 64:54-56.

Broadbent, P., J.B. Forsyth, K.P. Bevington, and R.J. Hutton. 1986. Citrus tree size control with dwarfing agents. Citrograph 72:8-10.

Castle, W.S. 1983. Growth, yield, and cold hardiness of seven-year-old Bears lemon trees on twenty-seven rootstocks. Proc. Fla. State Hort. Soc. 96:23-25.

Castle, W.S. 1992. Rootstock and interstock effects on the growth of young Minneola Tangelo trees. Proc. Fla. State Hort. Soc. 105:82-84.

Castle, W.S., D.P.H. Tucker, A.H. Krezdorn, and C.O. Youtsey. 1993. Rootstocks for Florida citrus. 2nd Ed. University of Florida, Gainesville, FL.
Cheng, F.S. and M.L. Roose. 1995. Origin and inheritance of dwarfing by the citrus rootstock Poncirus trifoliata Flying Dragon. Amer. Soc. Hort. Sci. 120:286-291.

DAVAR. 2010. Inventaire 2010 du verger calédonien et évaluation de la consommation de fruits frais. Gouvernement de la Nouvelle-Calédonie.

Golomb, A. 1988. High density planting of intensive citrus groves: A challenge and realization. Proc. Intl. Soc. Citriculture. p. 921-930.

ISEE. 2009. Recensement de la population. 21 Jan. 2011. <http://www.isee.nc/population/population. html $>$.

Joublan, J.P. and N. Cordero. 2002. Comportamiento de algunos cítricos sobre diferentes portainjertos, en su tercera temporada de crecimiento, Quillón, VIII Región, Chile. Agricultura Técnica (Chile) 62:469-479.

Krezdorn, A.H. 1978. Interstocks for tree size control in citrus. Proc. Fla. State Hort. Soc. 91:50-52.

Mademba-Sy, F., S. Lebegin, and J.P. Lyannaz. 1994. Characterization and performance of 51 citrus varieties in New Caledonia. Fruits 49:362-370.

Ollitrault, P. 1990. Isozymes and DNA Restriction Fragment Length Polymorphisms (RFLP's) as genetic markers in citrus selection. Proc. AsiaPacific Intl. Conf. Cit. p. 57-68.

Piner, G.F. 1988. Planting citrus at ultra high densities. A review of developments in Southern Africa with special reference to angle planting. Proc. Intl. Soc. Citriculture. p. 931-940.

Reforgiato Recupero, G., A. Caruso, and G. Russo. 1992. The Flying Dragon trifoliate orange and BA-300 citrange: Effects on scion performance. Proc. Intl. Soc. Citriculture. 1:286290.

Roose, M.L. 1986. Dwarfing rootstocks for citrus. Proc. Intl. Soc. Citrus Nurserymen. p. 1-8.

Stuchi, E.S., L.C. Donadio, and O.R. Sempionato. 2003. Performance of 'Tahiti Lime' on Poncirus trifoliata var. monstrosa Flying Dragon in four densities. Fruits 58:13-17.

Webster, A.D. 1997. A review of fruit tree rootstock research and development. Acta Hort. 451:53-73.

Webster, A.D. 2004. Vigor mechanisms in dwarfing rootstocks for temperate fruit trees. Acta Hort. 658:29-41.

Whitney, J.D., T.A. Wheaton, W.S. Castle, and D.P.H. Tucker. 1995. Tree height, fruit size, and fruit yield affect manual orange harvesting rates. Proc. Fla. State Hort. Soc. 108:112-118. 